\title{
Facilitators and obstacles in instituting of early identification and brief intervention in Catalonia
}

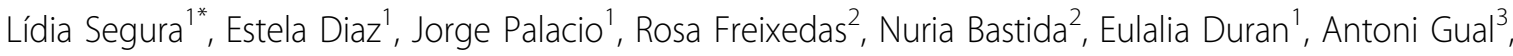 \\ Joan Colom ${ }^{1}$ \\ From International Network on Brief Interventions for Alcohol Problems (INEBRIA) Meeting 2011 \\ Boston, MA, USA. 21-23 September 2011
}

In Catalonia, the implementation of early identification and brief intervention (EIBI) started in 2002. Since then, through an iterative process consisted of two consecutive phases, significant improvements have been achieved in the number of professionals involved, in the level of screening conducted in primary care, and in the referral of people with alcohol use disorders to specialty care. Nevertheless, some elements still need to be addressed to achieve widespread adoption of EIBI. In this presentation, we review the elements identified as facilitators and obstacles to this process. The information comes from process indicators, from ongoing evaluation of results following implementation of the program, and from qualitative information gathered through surveys and interviews with participants in the referral network. Among the facilitators are the creation of the alcohol treatment referral network and the ongoing support for this network, peer-to-peer training, coordination between primary and specialist care, and inclusion in contractual incentives. Barriers included diversity of medical records available, lack of standardized tools for monitoring of action, and lack of a reliable system to monitor implementation in primary care. Once adequate training is available and a positive attitude toward EIBI has been achieved for all involved, one of the chief obstacles facing any health-care system is the institutionalizing the necessary work tools in the available clinical histories. In Catalonia this represents a challenge since there are 27 providers using nine different MR, with the resulting difficulties for integrating and monitoring results.

\footnotetext{
Author details

${ }^{1}$ Program on Substance Abuse, Catalonia Department of Health, Barcelona, Spain. ${ }^{2}$ Working Group on Alcohol, Catalan Society of Family and

${ }^{1}$ Program on Substance Abuse, Catalonia Department of Health, Barcelona, Spain

Full list of author information is available at the end of the article
}

Community Medicine, Catalonia Department of Health, Barcelona, Spain. ${ }^{3}$ Hospital Clínic of Barcelona Addictions Unit, Barcelona, Spain.

Published: 9 October 2012

doi:10.1186/1940-0640-7-S1-A33

Cite this article as: Segura et al:: Facilitators and obstacles in instituting of early identification and brief intervention in Catalonia. Addiction Science \& Clinical Practice 2012 7(Suppl 1):A33.
Submit your next manuscript to BioMed Central and take full advantage of:

- Convenient online submission

- Thorough peer review

- No space constraints or color figure charges

- Immediate publication on acceptance

- Inclusion in PubMed, CAS, Scopus and Google Scholar

- Research which is freely available for redistribution

Submit your manuscript at www.biomedcentral.com/submit

\section{() Biomed Central}

C Biomed Central

C 2012 Segura et al; licensee BioMed Central Ltd. This is an Open Access article distributed under the terms of the Creative Commons Attribution License (http://creativecommons.org/licenses/by/2.0), which permits unrestricted use, distribution, and reproduction in any medium, provided the original work is properly cited. 